\title{
МЕЖДУНАРОДНАЯ ТРУДОВАЯ МИГРАЦИЯ: ПРОБЛЕМЫ ОЦЕНКИ И ВЛИЯНИЕ НА СОЦИАЛЬНО-ЭКОНОМИЧЕСКОЕ И ДЕМОГРАФИЧЕСКОЕ РАЗВИТИЕ РЕСПУБЛИКИ БЕЛАРУСЬ
}

\author{
Т.В. КУЗЬМИЦКАЯ \\ Зав.сектором \\ Сектор социально-трудовых отношений и демографии \\ Институт экономики НАН Беларуси, г. Минск \\ Л.П. ШАХОТЬКО \\ Д.с.н., проф., гл. науч. сотрудник \\ Сектор социально-трудовых отношений и демографии \\ Институт экономики НАН Беларуси, г. Минск
}

\begin{abstract}
Аннотация
Рассмотрена специфика сочиально-экономического $и$ демографического развития Республики Беларусь на современном этапе. Установлено, что в сложившихся условиях возрастает роль международной трудовой миграции, а значит, усиливается актуальность выработки адекватной миграџионной политики. Проведен анализ международной трудовой миграции в Республике Беларусь, дана оиенка ее масштабов и предложены направления совершенствования миграционной политики.
\end{abstract}

Abstract

The specificity of the socio-economic and demographic development of the Republic of Belarus at the present stage was considered. Found that under the circumstances, the role of international labor migration increases, and thus enhanced the relevance of developing adequate migration policy. Held the analysis of international labor migration in the Republic of Belarus, held an assessment of its scope and proposed the directions of migration policy.

\section{ВВЕДЕНИЕ}

Курс на устойчивое социально-экономическое развитие страны требует выявления и мобилизации всех ресурсов, необходимых для его реализации, и обуславливает необходимость выполнения целого комплекса задач во всех сферах деятельности. Таких, как обеспечение экономического роста и процветания на основе труда, предпринимательской энергии и созидательной инициативы людей; формирование эффективных трудовых отношений и рынка труда, единой системы занятости. В настоящее время в Республике Беларусь остро стоит вопрос проведения модернизации экономики. И, поскольку на сегодняшний день модернизация упирается 
в нехватку квалифицированной рабочей силы, то на первое место выходят мероприятия по формированию эффективного рынка труда Республики Беларусь, сохранению трудового потенциала и удержанию в стране квалифицированных кадров. В этих условиях повышается значение трудовой миграции.

Понять такой сложный социально-экономический феномен, как миграция, без учета ее взаимосвязи с демографической обстановкой и экономическим развитием страны и ее регионов невозможно. На трудовой потенциал уже несколько лет оказывает неблагоприятное влияние демографическая ситуация, так как в Республике Беларусь, как и в ряде других развитых стран, численность населения в трудоспособном возрасте ежегодно убывает за счет превышения количества выходящих из трудоспособного возраста над количеством вступающих в него. Для решения этой проблемы необходимо повысить эффективность использования имеющихся трудовых ресурсов, а также привлечения новых, за счет роста их территориальной мобильности внутри республики и международной трудовой миграции. Нельзя управлять миграцией, не имея научно-обоснованных сценариев развития. Для того чтобы регулировать любой социальноэкономический процесс, в том числе и миграционный, необходимо знать текущее состояние объекта, тенденции его развития, пределы и инструменты возможного воздействия на этот процесс. Также при выработке миграционной политики следует учитывать, что в настоящее время обостряется глобальная борьба за трудовые ресурсы.

\section{РЕЗУЛЬТАТЫ И ИХ ОБСУЖДЕНИЕ}

\section{Анализ социально-экономического и демографического развития Республики}

Беларусь. Несмотря на явные негативные тенденции в динамике рождаемости и смертности в 1990-е гг. и начале первого десятилетия XXI века, а также депопуляции, которая длится уже два десятилетия, экономика Беларуси до последнего времени почти не ощущала реальных негативных последствий этих явлений. Это связано с тем, что в стране продолжали расти как абсолютная численность населения в трудоспособном возрасте, так и ее доля в общей численности. Начиная со второй половины первого десятилетия XXI века, сложившаяся структура населения по полу и возрасту в целом благоприятствовала демографическому развитию страны. Наблюдалось равновесие соотношения полов в наиболее активных брачных и детородных возрастах. Благоприятная половозрастная структура последних лет оказала положительное влияние на демографические процессы Беларуси в 2003-2012 гг. В результате количество браков несколько увеличилось, количество умерших - уменьшилось, количество родившихся - выросло. [1]

В последние годы ситуация изменилась. Уже на начало 2008 года абсолютная численность населения в трудоспособном возрасте впервые уменьшилась, а с 2009 года начала уменьшаться и доля населения в трудоспособном возрасте. Новая тенденция сохранится достаточно длительное время (примерно, 15-20 лет), причем темпы ее будут расти. Уменьшение численности населения в трудоспособном возрасте будет увеличивать демографическую нагрузку на трудоспособное население и, если к этому не быть готовым, может вызвать целый ряд негативных явлений 
социально-экономического характера. Со временем это может вызвать дефицит и структурный дисбаланс трудовых ресурсов, которые начинают проявляться уже в настоящее время. Несмотря на то, что на протяжении ряда последних лет ситуация в республике характеризовалась высоким уровнем занятости населения и низким уровнем безработицы, ростом спроса на рабочую силу и снижением регистрации безработных, в стране наблюдается дисбаланс спроса и предложения рабочей силы, неэффективная занятость и диспропорция по численности занятых по основным видам экономической деятельности. Трудовые ресурсы страны обладают достаточно высоким образовательным и профессиональным потенциалом, тем не менее, социологические опросы более 2,4 тыс. организаций различных форм собственности, проведенные НИЭИ Минэкономики в 2012 году, показали, что дефицит квалифицированных кадров становится основным сдерживающим фактором развития организаций на перспективу. Об этом заявило более 60 процентов опрошенных руководителей. Уже сейчас экономика страны ощущает существенный спад практически всех основных показателей состояния и использования трудовых ресурсов (табл. 1).

Таблица 1 - Состояние и использование трудовых ресурсов в Республике Беларусь за 20052012 гг.

\begin{tabular}{|c|c|c|c|c|c|c|c|c|}
\hline & 2005 & 2006 & 2007 & 2008 & 2009 & 2010 & 2011 & 2012 \\
\hline $\begin{array}{l}\text { Численность } \\
\text { трудовых ресурсов, } \\
\text { тыс. чел. }\end{array}$ & 6106,1 & 6107,7 & 6109,9 & 6108,0 & 6081,4 & 6078,5 & 6031,4 & 6030,0 \\
\hline $\begin{array}{l}\text { Численность } \\
\text { трудоспособного } \\
\text { населения в } \\
\text { трудоспособном } \\
\text { возрасте, тыс. чел. }\end{array}$ & 5838,2 & 5838,2 & 5825,0 & 5804,4 & 5777,8 & 5742,0 & 5694,9 & 5637,4 \\
\hline $\begin{array}{l}\text { Численность } \\
\text { населения, занятого в } \\
\text { экономике, тыс. чел. }\end{array}$ & 4414,1 & 4470,2 & 4518,3 & 4610,5 & 4643,9 & 4565,9 & 4554,5 & 4577,1 \\
\hline $\begin{array}{l}\text { Численность } \\
\text { экономически } \\
\text { активного населения, } \\
\text { тыс. чел. }\end{array}$ & 4490,6 & 4534,4 & 4566,9 & 4654,2 & 4685,1 & 4705,1 & 4686,0 & 4605,6 \\
\hline $\begin{array}{l}\text { Доля лиц, старше } \\
\text { трудоспособного } \\
\text { возраста в составе } \\
\text { трудовых ресурсов, в } \\
\%\end{array}$ & 4,4 & 4,4 & 4,7 & 5,0 & 5,0 & 5,5 & 5,6 & 6,5 \\
\hline $\begin{array}{l}\text { Численность } \\
\text { безработных, тыс. чел. }\end{array}$ & 67,9 & 52,0 & 44,1 & 37,3 & 40,3 & 33,1 & 28,2 & 24,9 \\
\hline $\begin{array}{l}\text { Количество вакансий, } \\
\text { тыс. (на конец года) }\end{array}$ & 35,8 & 44,8 & 50,8 & 50,7 & 34,5 & 48,8 & 51,7 & $\begin{array}{l}62,0- \\
70,6 \\
\text { август }\end{array}$ \\
\hline $\begin{array}{l}\text { Уровень безработицы, } \\
\%\end{array}$ & 1,5 & 1,2 & 1,0 & 0,8 & 0,9 & 0,7 & 0,6 & 0,5 \\
\hline
\end{tabular}

Источник: Экспертно-медийный семинар Трудовая миграция в союзном государстве состояние и перспективы. Информационный материал Минск 26 сентября 2013 г. С.40-43

Численность трудоспособного населения в трудоспособном возрасте и численность экономически активного населения уменьшается, доля лиц старше трудоспособного возраста в 
составе трудовых ресурсов растет, численность безработных уменьшается, количество вакансий растет. [2]

Однако на протяжении нескольких ближайших лет страна все еще не будет испытывать острого дефицита трудовых ресурсов. Это связано с тем, что, во-первых, в стране есть резервы за счет скрытой безработицы, что позволит сгладить ситуацию за счет более эффективного использования имеющихся трудовых ресурсов, во-вторых, законодательно трудоспособный возраст начинается с 16 лет, но в реальной жизни молодежь в этом возрасте продолжает учиться, а начинает работать на 5-8 лет позже. Следовательно, в настоящее время начинают работать те, кому 21-25 лет, то есть родившиеся в конце 80-х годов прошлого столетия, а те малочисленные когорты, которые родились в конце 90-х годов, начнут свою трудовую деятельность только в конце второго десятилетия текущего столетия. Многочисленные когорты родившихся в послевоенные 50-60-е годы уже начали выходить на пенсию, и это продлится до конца второго десятилетия. Поэтому сочетание этих двух факторов приведет к значительному сокращению численности потенциальных работников во второй половине второго десятилетия.

Если заранее не предпринять соответствующие меры, может возникнуть дефицит трудовых ресурсов. Поэтому в настоящее время качественное составление демографических прогнозов и выработка адекватной миграционной политики становятся особенно актуальными. Частично дефицит трудовых ресурсов можно будет решить за счет использования новых источников пополнения трудовых ресурсов. Среди возможных источников увеличения численности трудового потенциала следует выделить следующие: 1) совершенствование системы пенсионного обеспечения; 2) увеличение занятости инвалидов, тем более что современные технологии позволяют расширить возможности для этого; 3) повышение эффективности работы секторов бюджетной сферы. В настоящее время в стране предпринимаются меры в этом направлении; 4) рост территориальной мобильности трудовых ресурсов как внутри республики, так и внешней трудовой иммиграции.

В условия депопуляции компенсировать убыль населения предстоит миграции. Поэтому государство заинтересовано в притоке населения в республику и стремится проводить в стране эффективную миграционную политику, направленную на активное привлечение иммигрантов, особенно из стран СНГ, их успешную интеграцию в белорусское общество и нейтрализацию возможных отрицательных последствий. Однако, как показывают исследования последних лет, возможности у страны полностью погасить депопуляцию за счет притока молодежи из стран СНГ и Балтии практически отсутствует. Кроме того, следует изучить и хорошо взвесить все позитивные и негативные последствия миграции (как иммиграции, так и эмиграции) для социально-экономического, демографического и политического развития Республики Беларусь. Необходимо концептуально более четко определить: когда, сколько, каких и куда конкретно иммигрантов на постоянное место жительства стране необходимо привлечь. В некоторых случаях проблему целесообразно решать другим путем. В частности при возникновении дефицита трудовых ресурсов возможны следующие меры: переход экономики на инновационный путь 
развития; модернизация производства; рост производительности общественного труда; повышение квалификации и организации имеющегося трудового потенциала; более широкое использование посильного труда пенсионеров, инвалидов, учащейся молодежи или привлечение временных трудовых мигрантов на основе договоров и контрактов.

Миграционный прирост населения в Беларуси все последние 20 лет оставался положительным. В последние годы положительное сальдо миграции населения в Беларусь из стран СНГ и Балтии значительно увеличилось, и по отчетным данным сальдо миграции с другими странами мира в целом стало тоже положительным (рис.1).

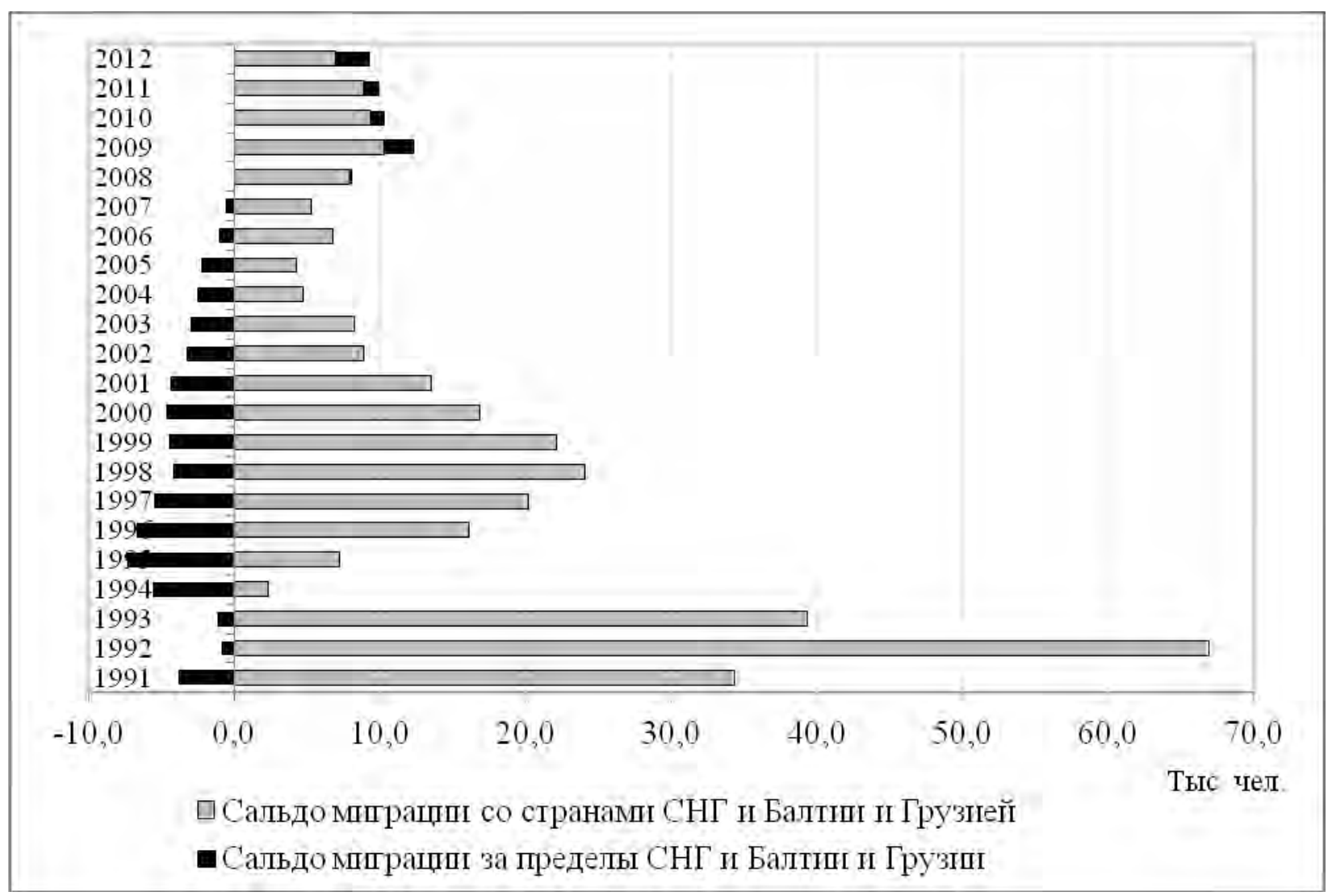

Рисунок 1 - Динамика объемов сальдо внешней миграции населения Беларуси по основным потокам

В 2013 году в стране впервые за годы депопуляции миграционный прирост в полтора раза перекрыл убыль населения за счет естественного оттока (рис. 2). 


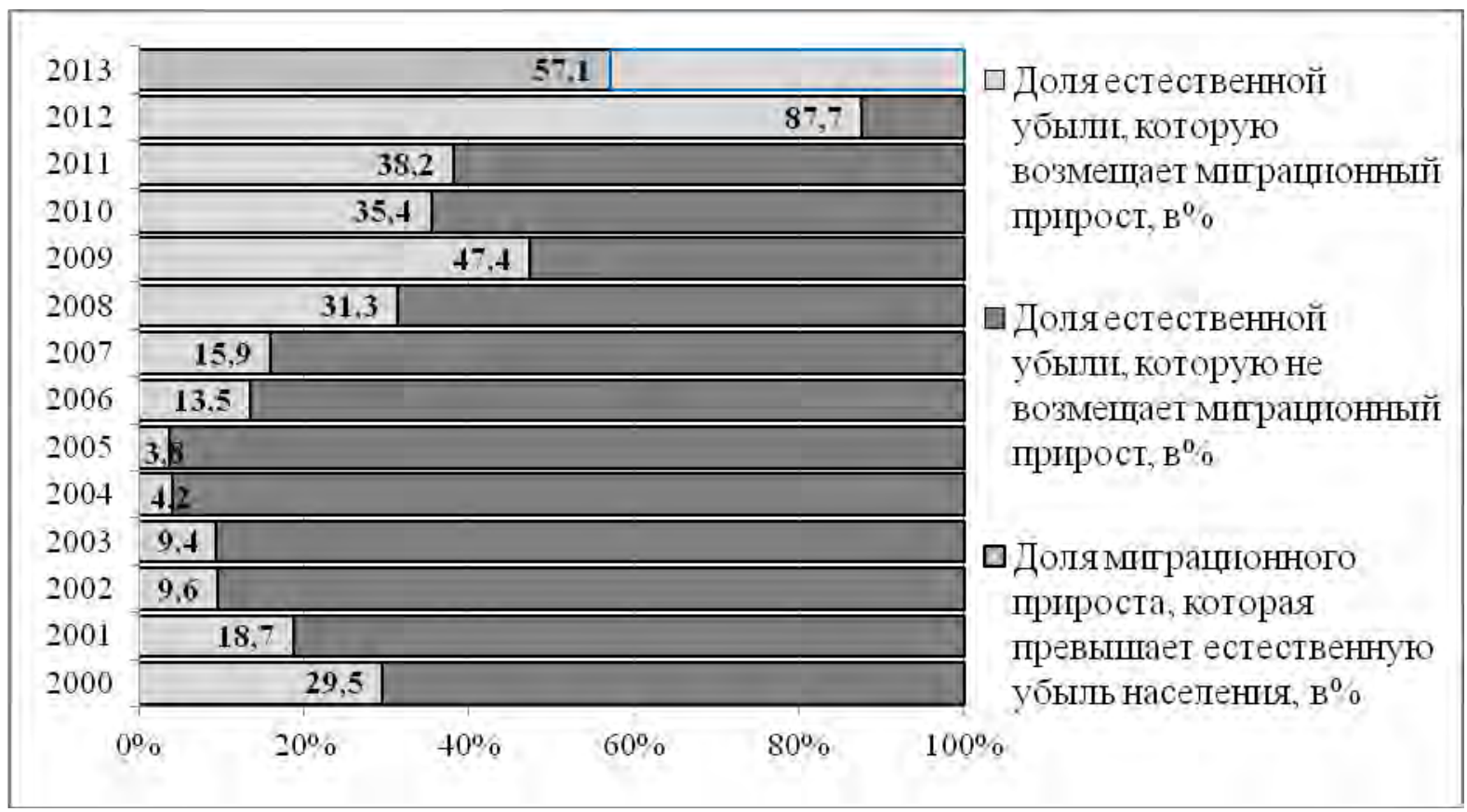

Рисунок 2 - Доля естественной убыли населения, которую возместил миграционный прирост в 2005-2013 гг.

Тем не менее, этот прирост остается незначительным и нельзя рассчитывать на то, что он позволит длительное время полностью компенсировать естественную убыль населения страны, тем более в условиях, когда естественная убыль начнет увеличиваться. Республика Беларусь будет вынуждена привлекать трудовых мигрантов при обострении дефицита трудовых ресурсов. Однако следует учитывать, что это должны быть квалифицированные работники и оплачиваться их труд должен так же, как труд граждан Беларуси. Привлекать в страну неквалифицированных разнорабочих и получать эффект за счет более низкой оплаты труда трудовых мигрантов - путь «в никуда». Как свидетельствует международный опыт, это позволяет сгладить проблему в краткосрочном периоде, но не решает ее в долгосрочном периоде, принося дополнительные сложности. Так как, во-nервых, тормозит развитие прогресса в механизации тяжелого ручного труда, во-вторых, может привести к обострению социальной обстановки в стране.

Проблемы учета трудовой миграции. В настоящее время остро стоит вопрос учета трудовой миграции. Причем это проблема не только Беларуси. Дело в том, что до сих пор не существует единой трактовки понятия трудовой миграции. Использование различных определений и отсутствие согласованных критериев отнесения к международным трудовым мигрантам в разных странах мира, влечет за собой многообразие методик измерения миграции, что существенно затрудняет международные сопоставления статистических данных. Поэтому вопрос гармонизации определений при определении миграции является особенно актуальным при анализе ее масштабов. Помимо этого, проблемы оценки международной миграции в значительной степени обусловлены высокой степенью эластичности составляющих ее видов и форм. Это связано с тем, что мигранты по социально-экономическим, политическим или экологическим причинам и трансформациям в стране прибытия или выбытия могут изменить свой статус. Так, безвозвратные мигранты (выехавшие в другую страну на постоянное место жительства как 
эмигранты) могут по каким-то причинам принять решение о возвращении на родину. Трудовые мигранты, легально находящиеся и официально работающие в стране трудоустройства, могут захотеть остаться в стране сверх разрешенного срока или попытаться сменить место работы, невзирая на ограничения, прописанные в контракте, и таким образом превратятся в незаконных мигрантов. Незаконно находящиеся в стране иммигранты могут «попасть» под миграционную амнистию (т.е. государственную кампанию по легализации) и обрести законные основания для проживания и работы в стране. К сожалению, статистика международной миграции практически не учитывает такого рода факты, и выводы исследователей основываются часто на умозрительных заключениях. [3]

Одним из способов получения данных о потоках трудовой миграции является статистический учет выданных документов, необходимых для легального въезда и проживания в стране, однако при этом из поля зрения выпадают мигранты, въезжающих в страну без законного разрешения. Другим способом получения информации о международной трудовой миграции как в странах принимающих мигрантов, так и в странах преимущественно отдающих их, предоставляют выборочные обследования домашних хозяйств. При этом страны приема получают информацию о численности трудовых мигрантов из других стран, их качественном составе и степени их включенности в рынок труда, а страны выбытия - о причинах миграции и количественном и качественном составе выбывших, что позволяет провести оценку экономического эффекта от миграции. Выборочные обследования для изучения миграции могут проводиться либо в форме специализированного самостоятельного исследования, либо как составная часть других исследований. Иногда страны, как это сделал Национальный статистический комитет Республики Беларусь в 2009 г., отдельные вопросы о трудовой миграции включают в программу переписей населения.

Трудовые мигранты выезжают из страны и въезжают в нее как по официально заключенным договорам и контрактам, так и без них. Как показывают обследования, не все из них являются нелегальными мигрантами в полном значении этого слова, так как многие из них заключают договора и контракты не в своей стране, а в стране-реципиенте непосредственно с нанимателем. Сопоставление данных, полученных из разных источников (оценка на основе переписи населения, выборочного обследования домохозяйств, российских статистических данных) позволяет сделать вывод, что отток незарегистрированных трудовых мигрантов как минимум на порядок превышает зарегистрированную трудовую миграцию из страны. По нашему мнению, в настоящее время в Беларуси назрела необходимость организации и совершенствования учета граждан, работающих за рубежом, так как подавляющее большинство выезжает из страны, не пользуясь услугами по трудоустройству лицензированных агентств, а статистические данные стран приема не позволяют в полном объеме оценить и охарактеризовать миграционные потоки.

В соответствии с балансом трудовых ресурсов, при составлении которого использовались предварительные результаты выборочного обследования домашних хозяйств в целях изучения проблем занятости населения, в том числе и по вопросам, касающимся трудовой миграции, 
количество граждан Республики Беларусь трудоспособного возраста, работающих за границей, в 2012 году составило 55,4 тысяч человек или $0,9 \%$ от численности трудовых ресурсов. [4] Однако обследования домашних хозяйств как способ получения данных о миграции, также имеет определенные недостатки, обусловленные, во-первых, тем, что трудовые мигранты могут уехать в другую страну на работу, забрав с собой всю семью и в этом случае не у кого будет получить информацию, и, во-вторых, тем, что, не смотря на то, что информация, предоставленная домашними хозяйствами, может быть использована исключительно для формирования сводных статистических данных и органы государственной статистики гарантируют еe конфиденциальность, некоторые домохозяйства склонны к сокрытию сведений о родственникахмигрантах, например, из опасения предъявления к уплате налогов из доходов, полученных за рубежом.

Оценка масштабов трудовой миграции в Беларуси. Реформы в политической и экономической сфере создали предпосылки для вхождения республики в международный рынок труда. В этих условиях соблюдение государственных интересов объективно требует усиления влияния государства на структуру эмиграционных и иммиграционных потоков, предполагает совершенствование системы органов государственного управления, ответственных за координацию этой деятельности.

В стране идет постепенная активизация организованной трудовой миграционной подвижности населения. В настоящее время относительно точный статистический учет в Беларуси ведется только тех трудовых мигрантов, которые выезжают или въезжают в страну официально, по трудовым договорам и контрактам, заключенным в фирмах в Республике Беларусь. Следует отметить, что в связи с тем, что заключение трудовых договоров и контрактов через лицензированные агентства в Беларуси не является обязательной процедурой, зарегистрированная трудовая миграция на основе официальных контрактов демонстрирует нам лишь верхушку миграционного айсберга. Трудовые мигранты на законных основаниях могут самостоятельно трудоустроиться - найти работодателя и заключить с ним трудовой договор. А помимо граждан Союзного государства России и Беларуси, которым не требуется разрешения на работу, с началом функционирования Единого экономического пространства (ЕЭП) был принят пакет документов, защищающий права трудовых мигрантов на территории ЕЭП и предоставляющих им равные возможности с гражданами этих стран.

По данным департамента по гражданству и миграции МВД Республики Беларусь и органов статистики в 2012 году в страну по контрактам и договорам прибыло всего 8,8 тысяч человек и выбыло в другие государства 6,5 тысяч человек. До последнего времени в стране преобладал экспорт рабочей силы над импортом, т.е. в трудовой миграции страна являлась страной-экспортером рабочей силы. Причем трудовые мигранты выезжают как на Восток, в основном Россию, так и на Запад, в страны ЕС, США, Канаду. В последние пять лет ситуация несколько изменилась. В целом, как страна-реципиент Беларусь продолжает выступать в меньшей степени, принимая относительно небольшие потоки трудовых мигрантов без официальных договоров и контрактов из Молдовы и ряда других государств в основном на сельскохозяйственные и строительные работы. Существенно 
возросли объемы импорта трудовых мигрантов в страну, особенно мигрантов, въехавших в Беларусь на основе официальных договоров и контрактов (рис.3). [5]

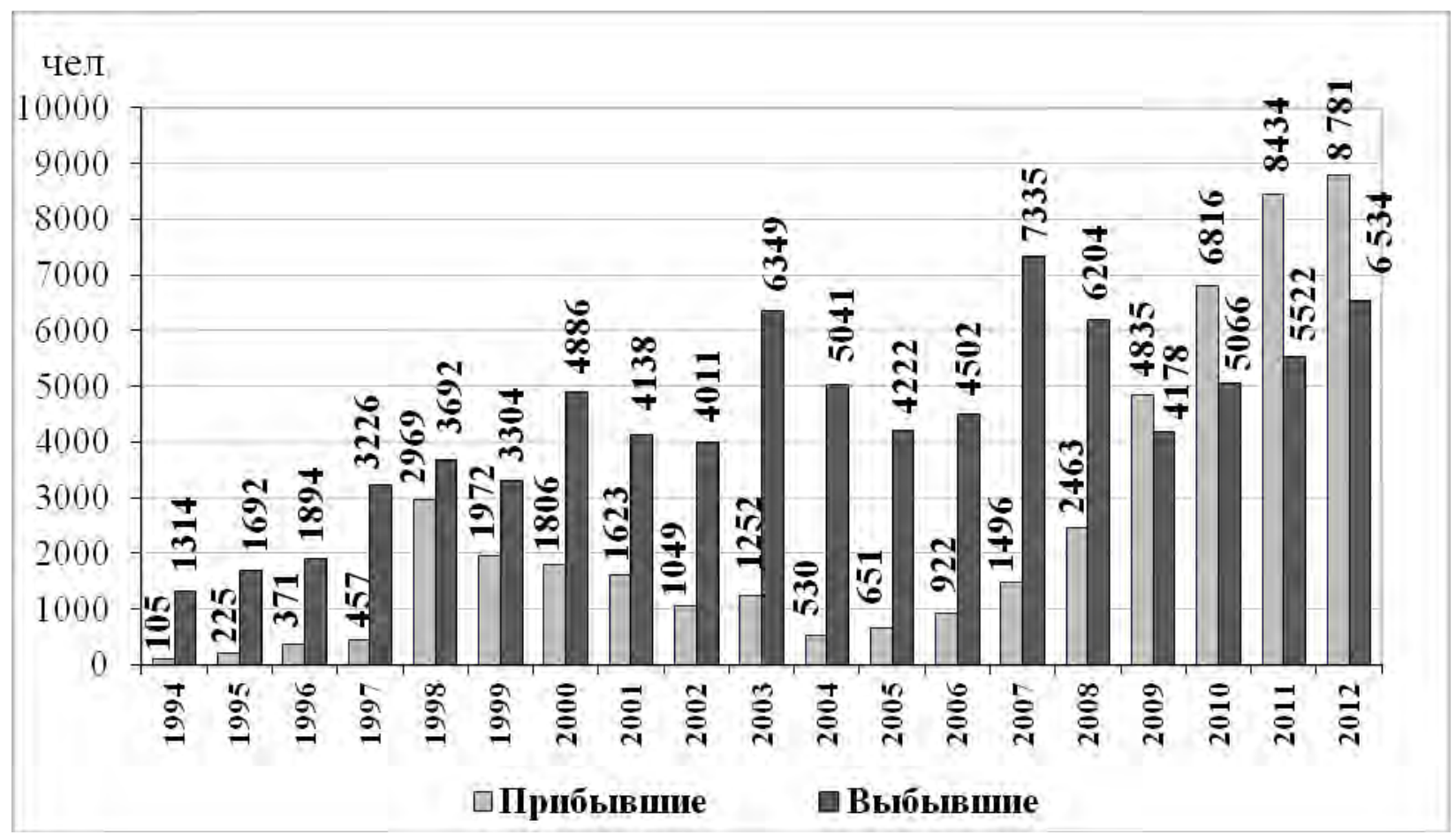

Рисунок 3 - Динамика численности трудящихся мигрантов выехавших из Беларуси и въехавших в страну на основе официальных договоров и контрактов 1994 -2012 гг.

Не смотря на то, что в связи с неполным учетом, объемы зарегистрированной международной трудовой миграции как минимум на порядок ниже фактических значений, в Беларуси миграция не носит столь масштабного характера, как озвучивается некоторыми экспертами. Например, по словам представителя Международной организации по миграции (MOM) в Беларуси Натальи Жак, за рубежом в 2012 году могло находиться от 800 тыс. до 1,2 млн. граждан Беларуси трудоспособного возраста. «Это не значит, что они уехали навсегда и не возвращаются, - отметила эксперт. - Они уезжают, возвращаются, они выезжают на сезонные работы, потом опять возвращаются, то есть это такая сезонная миграция»). [6] Во-первых, следует отметить, что значительная их часть по существующей классификации уже не является мигрантами, так как более года постоянно проживает за границей, но по тем или другим причинам не хочет или не может поменять гражданство. Во-вторых, в соответствии с балансом трудовых ресурсов за 2012 год [7] названные цифры трудовых мигрантов выглядят явно завышенными. Так, в 2012 году общая численность трудовых ресурсов в Беларуси составила 6 030,0 тыс. чел., в т.ч. занятое население - 4577,1 тыс. чел.; прочее трудоспособное население в трудоспособном возрасте - 1452,9 тыс. чел. В последнюю цифру (т.е. не занятое по трудовым договорам на предприятиях и в организациях Беларуси) включены 239,6 тыс. чел. безработных, подсчитанных по методологии международной организации труда (МОТ); 272,5 тыс. чел., находящиеся в отпусках по беременности и родам или по уходу за ребенком до достижения им трехлетнего возраста и получающих пособие; 497,4 тыс. чел. учащихся и студентов дневной (стационарной) 
формы обучения; 58,3 тыс. чел., получающих пособие по уходу за инвалидами или престарелыми, 16,2 тыс. чел., находящихся в заключении. Остается всего 368,9 тыс. чел., которые не имеют официальных источников доходов в Беларуси и не являющихся безработными. К ним относятся: лица, ведущие домашнее хозяйство (130,8 тыс. чел.); лица, полагающие, что найти в работу невозможно (42,0 тыс. чел.); лица, не имеющие необходимости или желания ее искать (30,2 тыс. чел.); прочие (110,5 тыс. чел) и собственно внешние трудовые мигранты (55,4 тыс. чел). Можно предположить, что граждан Республики Беларусь в трудоспособном возрасте работающих за границей, несколько больше, чем 55,4 тыс. чел., указанных в балансе трудовых ресурсов, так как возможно в ходе обследования домашних хозяйств не все опрошенные сообщили о себе достоверные сведения из боязни быть привлеченными к ответственности за неуплату налогов. Вместе с тем, очевидно, что все официально незанятые в Беларуси граждане не могут быть внешними трудовыми мигрантами, так как часть их задействована в теневом секторе экономике, а часть действительно ведет домашнее хозяйство либо не имеет необходимости, желания или возможности работать. По нашему мнению, в настоящее время правдоподобной представляется оценка внешней трудовой миграции в целом в размере не более 200-300 тыс. чел. или 4-5\% трудовых ресурсов Беларуси. Эта цифра соответствует оценкам российских и белорусских компетентных органов. [8] Необходимо отметить, что отток трудовых ресурсов из Беларуси за границу, хотя и не такой высокий, как в некоторых странах (Таджикистан, Молдова, Киргизия, Армения), тем не менее достаточно существенный, чтобы остро поставить вопрос о выработке миграционной политики в стране.

Так как большинство трудовых мигрантов из Беларуси выезжают на работу в Россию, большой научный и практический интерес представляют данные российской статистики о мигрантах - гражданах Беларуси. По состоянию на 02 февраля 2014 года по данным Федеральной миграционной службы Российской Федерации [9] на территории этой страны находилось 391695 граждан Республики Беларусь, в том числе 245823 мужчин и 145872 женщин, что составляет более 4\% от общей численности постоянного населения Беларуси, при чем 342324 человека из них - в возрасте от 18 до 59 лет. Для сравнения по состоянию на указанную дату в России находилось около 3,5\% от численности постоянного населения Украины, Армении - более 14\%, Киргизии - более $10 \%$, Молдовы - более 15\%, Таджикистана - более $14 \%$. Очевидно, что не все они являются трудовыми мигрантами, но вероятно значительная часть из них выехала в Россию с целью трудоустройства.

По данным Федеральной миграционной службы Российской Федерации в 2010 году было поставлено первично на миграционный учет 169 тысяч граждан Республики Беларуси, из которых 41918 человек указали в качестве цели прибытия «работа». [10] Однако использовать указанные данные в качестве всеобъемлющих и наиболее полно характеризующих миграционные потоки из Беларуси в Россию также не представляется возможным. Во-первых, процедура регистрации белорусов в России в реальности не является обязательной, так как, в соответствии с соглашениями о Союзном государстве России и Беларуси, не требуется получение разрешения на 
работу, а в дополнение к этому, недавно увеличен срок миграционного учета до 90 суток. Вовторых, отсутствует возможность удостовериться в том, что в миграционной карте был указан подлинный род занятий. Поэтому действительная численность трудовых мигрантов из Беларуси может в несколько раз превышать указанные данные. С большой долей вероятности в указанное выше число не входят мигранты, занятые на временных сезонных работах в сельском хозяйстве и строительстве, не оформляющие официально свои трудовые отношения с работодателем. В тоже время с определенной уверенностью можно утверждать, что 41918 человек - это краткосрочные мигранты из Беларуси, работавшие в России на протяжении от 3 до 12 месяцев в 2010 году. [11]

Социологическое исследование потенциала миграции в стране. В соответствии с социологическими исследованиями в Беларуси относительно невысокий уровень потенциальной внешней миграции населения: только 5,9\% опрошенных граждан хотели бы выехать за границу на постоянное место жительства. Результаты опросов свидетельствуют о том, что граждане Беларуси настроены преимущественно на временную трудовую миграцию, а не на смену постоянного места жительства. С точки зрения географических предпочтений респондентам наиболее привлекательными странами представляются Россия (16,4\%), Германия (15,0\%), США (12,7\%), Италия (7,3\%), Польша (6,5\%). Чем старше возраст потенциальных мигрантов, тем слабее выражена у них установка на переезд на постоянное жительство в другую страну. Так, большинство респондентов, планирующих эмиграцию, составляет категория людей в возрасте до 29 лет (62,2\%), доли других возрастных групп составили: от 30 до 39 лет - 18,0\%, от 40 до 49 лет $12,3 \%$, от 50 до 59 лет $-5,7 \%, 60$ лет и старше - 1,7\%. Причем более всего настроены на эмиграцию молодые люди из г. Минска (72,6\%) и Могилевской области $(91,1 \%)$. Доля респондентов в возрасте до 29 лет среди желающих выехать за границу на временную работу также является наибольшей, хотя и меньше, чем среди потенциальных эмигрантов, и составляет 44,5\%. Удельный вес других возрастов последовательно убывают: от 30 до 39 лет - 25,4\%, от 40 до 49 лет $-20,2 \%$, от 50 до 59 лет - 8,9\%, от 60 и старше - 1,0\%. Следует отметить, что возрастная структура респондентов заметно отличается в зависимости от места их жительства. Так, возрастная структура потенциальных трудовых мигрантов столицы Беларуси имеет следующий вид: до 29 лет - 56,0\%, от 30 до 39 лет - 17,5\%, от 40 до 49 лет - 14,5\%, от 50 до 59 лет - 9,6\%, 60 и старше $-2,4 \%$. Здесь хотя и прослеживается общая тенденция, но также видно, что жители столицы более старшего возраста легче принимают решение о трудовой миграции за пределы страны, чем жители других регионов Беларуси. Среди респондентов, которые хотели бы уехать за границу как на постоянное место жительство, так и на временную работу, преобладают граждане со средним (30,7\% и $35,8 \%$ соответственно) и средним специальным образованием $(26,8 \%$ и $36,2 \%)$, в то время как удельный вес граждан, имеющих высшее образование, значительно ниже (14,6\% и 12,7\% соответственно). Согласно обследованию, основными причинами, побуждающими респондентов задуматься о выезде, являются следующие: желание улучшить свое материальное положение (46,5\%); желание посмотреть мир, пожить и поработать в другой стране $(42,7 \%)$; желание обеспечить будущее детям, дать им хорошее образование (31,5\%); усталость от 
нестабильной, непредсказуемой жизни $(16,9 \%)$; желание заработать капитал для своего дела $(16,1 \%)$; желание повысить свой профессиональный уровень, квалификацию (12,9\%); стремление жить вместе со своими близкими, родственниками (8,2\%).

Следует отметить, что большинство респондентов, желающих эмигрировать либо какое-то время поработать в другой стране, оценивают материальное положение своих семей как среднее $(48,2 \%$ и $51,0 \%)$ или даже как хорошее $(10,8 \%$ и 4,8\%). Это свидетельствует о том, что за границу мигрантов выталкивает не бедность и безработица. Степень удовлетворенности потенциальных мигрантов своей нынешней работой находится на низком уровне. Вполне удовлетворены своей работой только 9,3\% респондентов, желающих уехать за границу на постоянное жительство, а среди респондентов, желающих выехать за границу на временную работу, их доля еще ниже $6,2 \%$. [12]

Предлагаемая в настоящее время в нашей стране заработная плата на уровне 400-500 долларов США не решает проблемы оттока кадров. По данным управления политики занятости Министерства труда и социальной защиты, в Беларуси становится все больше вакансий с зарплатой свыше 4 миллиона рублей. [13] Лидирует по этому показателю Минск, в котором 23,8\% от всех вакансий занимают свободные рабочие места с оплатой свыше 4 миллионов рублей. Среди других регионов республики максимальный показатель в Могилевской области (9,3\%), минимальный - в Гомельской области $(5,4 \%)$. Иными словами, отмечается устойчивая тенденция роста уровня оплаты труда по предлагаемым вакансиям. В тоже время, даже у самого бедного региона России - Дагестана - средняя начисленная заработная плата была выше, чем в любой из областей нашей страны. [14] Очевидно, что в условиях свободного движения рабочей силы в рамках Союзного государства и Единого экономического пространства (ЕЭП) невозможно удержать высококвалифицированных специалистов, не повышая заработную плату. Как справедливо отмечает С.Ю. Солодовников, «если мы этого делать не будем, то рискуем в ближайшее время потерять часть высококвалифицированных кадров. А без них все разговоры об инновационном развитии экономии будут лишены смысла». [15]

Следует отметить, что в Беларуси значительная часть доходов граждан не связана с их трудовым вкладом. По оценкам Всемирного банка в Беларуси масштабы социальной помощи самые значительные в регионе, общий объем расходов на социальную помощь составляет $2,7 \%$ ВВП при охвате почти половины населения страны. [16] При этом существующий категориальный механизм социальной помощи приводит к тому, что значительную часть пособий получают домашние хозяйства, которые не являются малообеспеченными. С одной стороны, существующая система позволяет решать социальные задачи, такие как полная занятость, низкий уровень бедности и др. С другой стороны, приводит к тому, что работники, ориентированные на высокую производительность труда при условии адекватной оплаты, не находят себе места в сложившихся условиях и уезжают за рубеж.

Плюсы и минусы международной трудовой миграции. Международная трудовая миграция имеет свои плюсы и минусы как для стран, отдающих рабочую силу, так и для 
принимающих стран. Страны-экспортеры рабочей силы в результате миграции получают следующие преимущества: благодаря миграции снижается давление на рынок труда, уменьшается уровень безработицы, а соответственно и социальной напряженности в стране; трудовые мигранты за границей могут повысить свою квалификацию, овладеть новыми технологиями и изучить более передовую организацию труда, а впоследствии, вернувшись на родину, использовать полученный опыт; приток валюты в страну через валютные переводы от трудовых мигрантов, которые они высылают своим родственникам; повышается уровень жизни и благосостояния домохозяйств трудовых мигрантов. Основными недостатками, которые несет международная трудовая миграция для стран-экспортеров являются следующие: к трудовой миграции чаще всего склонны лица, находящиеся в наиболее трудоспособном возрасте; страна теряет часть затрат, связанных с образованием и профессиональной подготовкой мигрантов (при «утечке умов»); возвратная трудовая миграция нередко трансформируется в эмиграцию, так как трудовые мигранты, которым удается хорошо обустроиться в принимающих странах, часто не планируют возвращение на родину. Для стран, преимущественно принимающих трудовых мигрантов, миграция приносит такие выгоды как снижение издержек производства, ведущее к повышению конкурентоспособности товаров вследствие использования более низкооплачиваемых мигрантов по сравнению с местными кадрами; высококвалифицированные мигранты получили образование и прошли профессиональную подготовку за счет другой страны; в случае спада производства иностранных рабочих часто увольняют в первую очередь, на них ограниченно распространяются социальные гарантии, пособие по безработице, социальное и пенсионное обеспечение; за счет приезжих работников увеличивается внутренний спрос на товары потребления. В то же время страны-импортеры рабочей силы могут получить такие проблемы как рост дискриминации и межнациональной розни; недовольство коренного населения и, соответственно, усиление социальной напряженности. Тем не менее, несмотря на расхожее мнение о невыгодности приема международных трудовых мигрантов, на практике баланс соотношения преимуществ и потерь от трудовой миграции чаще всего складывается в пользу принимающей страны.

В настоящее время трудовая миграция не оказывает сильного влияния на уменьшение численности занятых в экономике. Но при этом негативно сказывается и на возрастной структуре трудовых ресурсов, так как работать за границу выезжают преимущественно молодые трудоспособные кадры, и на профессионально-квалификационной структуре населения, так как в результате миграции происходит замещение работников с высоким уровнем образования и квалификацией менее образованными и квалифицированными работниками. При выработке миграционной политики необходимо учитывать, что временная трудовая миграция, которая зачастую оборачивается эмиграцией, вызвана не только недостатком высокооплачиваемых рабочих мест на родине. На принятие решений о миграции существенное влияние оказывают такие неэкономические причины, как уровень личной и общественной безопасности в стране, надежность правопорядка и отсутствие коррупции, лучшие жизненные перспективы для детей и 
т.д. Поэтому миграционную политику нельзя сводить к регулированию миграционных потоков. Миграционная политика - это широкий спектр мероприятий в сфере экономической, социальной, образовательной, региональной политики государства.

Поскольку трудовая миграция это комплексное и внутренне противоречивое явление, она оказывает разнонаправленное воздействие на социально-экономическое развитие страны. Для определения основных направлений миграционной политики рассмотрим выгоды и проблемы, получаемые Республикой Беларусь, являющейся в основном страной-экспортером рабочей силы. Основными преимуществами экспорта труда считаются:

- $\quad$ снижение уровня безработицы;

- использование полученного за границей опыта (повышение квалификации и овладение новыми технологиями) трудовых мигрантов при возращении на родину;

- у улучшение платежного баланса страны за счет притока валюты посредством переводов от трудовых мигрантов, высылаемых своим семьям;

- сокращение бедности и повышение благосостояния домохозяйств трудовых мигрантов.

В сложные для экономики Беларуси периоды трудовую миграцию в Россию стимулируют отсутствие языкового барьера, законодательно закрепленные равные права при трудоустройстве на более масштабном и диверсифицированном рынке труда, территориальная близость и высокая транспортная доступность, более высокий уровень заработной платы. Международная трудовая миграция служит амортизатором для смягчения колебаний на рынке труда вследствие спада производства, снижает напряженность на национальном рынке труда, уменьшает уровень безработицы. Однако максимальный положительный эффект от снижения напряженности на рынке труда вследствие миграции достигается при негативном типе отбора мигрантов - когда мигрантами становятся работники с худшим уровнем образования и квалификации, поскольку не могут найти себе работу в своей стране. Но, по оценке экспертов, при относительно низкой дифференциации доходов (как сейчас в Беларуси) и при существенной разнице в доходах между Беларусью и Россией преобладает позитивный отбор, то есть мигрируют самые продуктивные, производительные и активные граждане. [17] Поэтому чаще всего трудовыми мигрантами становятся не безработные, а квалифицированные специалисты в наиболее трудоспособном возрасте, востребованные на местном рынке труда, но не удовлетворенные предлагаемым уровнем оплаты, и в результате Беларусь хронически испытывает нехватку кадров в ряде отраслей экономики. Между тем, освобожденные в результате миграции рабочие места не удается заполнить по ряду причин: отсутствие доступного жилья в трудодефицитных регионах, дисбалансы в профессионально - квалификационной структуре трудовых ресурсов и др.

Причем, пока в стране не увеличится дифференциация заработной платы в пользу более производительных работников, представляется маловероятным возращение на родину трудовых мигрантов и использование полученного ими за границей передового опыта и новых технологий в рамках национальной экономики. 
В соответствии с официальной статистикой Национального банка денежные переводы белорусских мигрантов из-за рубежа составляют менее $1 \%$ от валового внутреннего продукта (ВВП) Беларуси. Но необходимо учитывать, что по оценкам экспертов из Всемирного банка, во всем мире официальные переводы от мигрантов составляют лишь около $29 \%$ от фактического объема поступлений. [18] С учетом этого в исследовании, проведенным А. Лученком и И. Колесниковой на основании методологии Всемирного банка, было рассчитано, что объем чистых поступлений от мигрантов может составлять около 850 млн. долларов США или 1,7\% ВВП. На основании исследования, проведенного В. Валетко, в 2012 году от трудовых мигрантов экономика Беларуси получила сумму в размере около 950 млн. долларов США, в том числе 60\% это доходы от трудовой миграции (люди, уехавшие на заработки на срок до года), 40\% поступления от диаспоры (постоянно живущих за рубежом). [19] Вместе с тем, оценить значимость и эффективность вклада трудовых мигрантов в поддержание сбалансированности платежного баланса и экономики страны в целом затруднительно по причине отсутствия достоверных данных о численности трудовых мигрантов, размерах их трансфертов и доли мигрантов, отправляющих своим семьям денежные переводы из-за границы. [20]

Опросы и выборочные обследования домашних хозяйств показывают, что средства, зарабатываемые трудовыми мигрантами, служат источником, позволяющим улучшить качество жизни, в первую очередь - жилищные условия, а не для инвестиций и сбережений. [21] Помимо приобретения жилья, доходы от трудовой миграции расходуются на образование и услуги здравоохранения, а также на покупку товаров длительного пользования, улучшения питания. Т.е. домохозяйства, в составе которых имеются трудовые мигранты, получают возможность улучшить свое благосостояние. Вместе с тем, рассматривать трудовую миграцию в качестве ключевого инструмента борьбы с бедностью применительно к условиям Беларуси будет неверно. Так как поступления от трудовых мигрантов хотя и повышают общий уровень благосостояния населения, но имеют низкую адресность по причине позитивного типа отбора трудовых мигрантов. Как отмечалось выше, основными причинами трудовой миграции белорусов являются не бедность и безработица, а желание улучшить свое материальное положение и более широкие возможности сделать карьеру, получить налоговые преимущества для ведения бизнеса в странах с более либеральным законодательством и большим распространением частного сектора. Это приводит к тому, что в Беларуси трудовыми мигрантами зачастую становятся относительно обеспеченные городские жители, имеющие материальные потребности значительно выше тех, которые представляется возможным удовлетворить, работая в Беларуси. В то же время, альтернативные подходы к оценке влияния трудовой миграции на уровень бедности в стране показывают, что в условиях отсутствия денежных переводов уровень бедности населения, полагающегося на помощь родных, возрастет. [22]

Основными издержками внешней трудовой миграции для стран экспортеров рабочей силы являются следующие: ухудшение демографической ситуации в результате изменений в половозрастной структуре населения; «утечка умов»; финансовые издержки, связанные с потерей 
части расходов, понесенных на обучение и профессиональную подготовку мигрантов и увеличением налоговой нагрузки в связи недополучением части взносов в фонды социального страхования, пенсионного и медицинского обеспечения.

Негативное влияние трудовой миграции на экономику нашей страны проявляется в следующем:

Из Беларуси «вымываются» мобильные, молодые, талантливые, квалифицированные трудовые кадры, востребованные на отечественных предприятиях, дефицит которых в полной мере не удается восполнить ни за счет безработных, ни за счет трудовых мигрантов из других стран.

Возникают дисбалансы в половозрастной структуре трудовых мигрантов, обусловленные повышенным спросом на российском рынке труда, на который по оценкам экспертов устремляется около 90\% всех белорусских мигрантов, на работников, обладающих традиционно мужскими профессиями и специальностями. В России около половины трудовых мигрантов из Беларуси занято в строительстве, значительная часть - на транспорте и т.д. В соответствии с исследованиями среди уезжающих на работу в Россию преобладают мужчины, а доля женщин составляет всего около 9,4\%. В то время как гендерная структура белорусских мигрантов, работающих в остальных странах, более соответствует структуре трудовых ресурсов Беларуси, доля женщин составляет в ней около трети. [23] В совокупности перечисленные факты неблагоприятно сказываются на уровне рождаемости в Беларуси, ведут к росту распавшихся семей.

Так как мигрантами в Беларуси чаще всего становятся обученные и подготовленные квалифицированные специалисты, то страна теряет часть средств, вложенных в образование и профессиональную подготовку, причем, в случае успешного развития карьеры за рубежом рассчитывать на возвратность трудовой миграции не приходится. Так же страна не дополучает часть отчислений в Фонд социальной защиты населения, из-за чего возникает дополнительная нагрузка на работающее в Беларуси население.

Доходы от трудовой миграции не используются в качестве источника финансирования инвестиций и модернизации промышленности, так как полученные трансферты в соответствии с проведенными исследованиями большей частью «проедаются».

\section{ВЫВОДЫ}

Как показали наши исследования, полностью и надолго погасить депопуляцию в стране в ближайшие годы не представляется возможным. Таким образом, демографическая безопасность и в долгосрочной перспективе будет выступать одним из наиболее проблемных аспектов социальной безопасности, требующего к себе повышенного внимания. Успешность социальноэкономического развития Республики Беларусь сегодня во многом зависит от того, сумеет ли страна перейти к инновационному пути развития. Комплексная модернизация неразрывно связана с количественными и качественными характеристиками трудовых ресурсов (отток - приток), 
качеством подготовки иностранцев в нашей стране и обучения белорусов за рубежом. Необходимо разработать и внедрить хозяйственные механизмы, стимулирующие экономический рост, предотвращающие отток высококвалифицированных кадров за границу и привлекающие необходимых специалистов в Беларусь. Так как, на принятие решений о миграции существенное влияние оказывают неэкономические причины, то выработка миграционной политики не исчерпывается регулированием миграционных потоков, а включает в себя широкий комплекс мероприятий в сфере экономической, социальной, образовательной, региональной политики государства. Поэтому способствовать решению проблемы сохранения кадрового потенциала Беларуси будут мероприятия, направленные на повышение прозрачности соотношения трудового вклада, доходов, расходов и благосостояния населения:

1. Для предотвращения оттока высококвалифицированных кадров за границу необходимо увеличивать общий уровень оплаты труда в стране и усилить его дифференциацию в зависимости от качества труда, особенно в приоритетных для государства отраслях, так как главной причиной выезда в настоящее время является неудовлетворенность уровнем заработной платы. Рост доходов будет способствовать снижению текучести кадров на предприятиях Беларуси, а также стимулировать возвратную трудовую миграцию.

2. Для повышения территориальной трудовой мобильности необходимо строить государственное жилье и предоставлять его в аренду по доступным ценам в тех населенных пунктах, в которых наблюдается дефицит рабочей силы. В стране уже предприняты определенные шаги в данном направлении, вместе с тем имеется значительный потенциал для совершенствования. По нашему мнению, следует также пересмотреть принципы выделения арендного жилья, чтобы претендовать на него могли не только лица, нуждающиеся в улучшении жилищных условий. Одним из основных критериев для первоочередного предоставления арендного жилья из государственного жилого фонда должна являться не длительность нахождения в списке нуждающихся, а востребованность работников такой специальности на рынке труда в данном регионе. Необходимо внедрить в практику финансирование строительства арендного жилья организациями и предприятиями, испытывающими нехватку специалистов. Доработать и запустить рыночные механизмы, способствующие тому, чтобы трудоспособные граждане могли без помощи государства заработать, накопить и сберечь от инфляции деньги на жилье, или приобрести его в кредит по доступным процентным ставкам (жилищные облигации, ипотека).

3. Предоставлять в бессрочное безвозмездное пользование социальное жилье незащищенным слоям населения и членам их семей, таким как инвалиды, многодетные семьи; оказывать государственную поддержку малообеспеченным слоям населения в виде строительства жилья по доступным ценам и с предоставлением кредитов по льготной процентной ставке только при установлении ряда ограничений на основании опыта западных стран, в соответствии с которыми в случае улучшения материального положения таких семей, наличия у них в собственности дорогостоящих автомобилей, происходит сокращение или лишение социальной 
поддержки. Усилить ответственность за нецелевое использование полученной государственной поддержки.

4. Развитию рыночных отношений будет способствовать установление в качестве приоритетного принципа государственных программ, предусматривающих оказание материальной помощи нуждающимся группам населения, стимулирование их активности для самостоятельного решения экономических проблем, т.е. предоставление каждому трудоспособному человеку возможности своим трудом и предприимчивостью обеспечить семейное благосостояние. Люди, занятые в общественном производстве, не должны попадать в категорию малообеспеченных. В связи с этим необходим пересмотр подходов к системе социальной защиты с целью увеличения адресной помощи малообеспеченным семьям и гражданам и снижению объемов льгот и субсидий в сфере жилищно-коммунального хозяйства, жилищного строительства, на транспорте и др., предоставляемых по уравнительному принципу всем категориям населения, независимо от их доходов и степени нуждаемости. Совершенствование социальной политики, включающей политику регулирования доходов, политику социальных гарантий, политику социальной защиты, а также защиты здоровья и экологической безопасности.

На современном этапе Республике Беларусь все еще удается сохранить достаточно квалифицированный трудовой потенциал и поэтому необходимо создать условия, чтобы он был максимально задействован внутри страны. Для решения проблем занятости, возникающих на рынке труда, не стоит стимулировать внешнюю трудовую миграцию. Замещение вакантных рабочих мест, образующихся в связи с оттоком высококвалифицированных работников за рубеж, прежде всего в Россию, за счет массового привлечения дешевой рабочей силы из менее индустриально развитых среднеазиатских стран СНГ и Юго-Восточной Азии, впоследствии может принести новые проблемы. Беларусь не находится на той стадии деиндустриализации, которая требует масштабного промышленного строительства и столь же массового привлечения и подготовки кадров. Проводить политику выборочной миграции. Привлекать специалистов из других стран следует только с использованием механизма фильтрации мигрантов, позволяющего отбирать работников, обладающих необходимыми специальностями и квалификацией. В частности, для стран не членов ЕЭП может быть использовано квотирование мигрантов по определенным специальностям; для сохранения и привлечения высококвалифицированных кадров могут быть установлены специальные поощрительные меры и гранты.

\section{ЛИТЕРАТУРА}

1. Демографический ежегодник Республике Беларусь. Национальный статистический комитет Республики Беларусь. - Минск, 2013.

2. Трудовая миграция в союзном государстве - состояние и перспективы. // Трудовая миграция в союзном государстве - состояние и перспективы : Информационный материал экспертно - медийного семинара (26 сентября 2013 г.), - 2013. - С.40-43 
3. Чудиновских, О. Статистика трудовой миграции в странах сети МИРПАЛ / О.Чудиновских // Всемирный банк (The World Bank Group) [Электронный ресурс]. - 2013 - Режим доступа : http://siteresources.worldbank.org/INTECA/Resources/ChudinovskikhDec19Rus.doc Дата доступа : 12.09.2013

4. Статистический бюллетень «Трудовые ресурсы и занятость населения Республики Беларусь в 2012 году». / Национальный статистический комитет Республики Беларусь. - Минск, 2013. - C.3-4.

5. Демографический ежегодник Республике Беларусь. Национальный статистический комитет Республики Беларусь. - Минск, 2013.

6. МОМ: Миллион белорусов работает за границей // BelaNews.ru [Электронный pecypc]. 2013. - Режим доступа : http://belanews.ru/2013/01/05/33834/ Дата доступа : 22.11.2013

7. Статистический бюллетень «Трудовые ресурсы и занятость населения Республики Беларусь в 2012 году». / Национальный статистический комитет Республики Беларусь. - Минск, 2013. - C.3-4.

8. По приблизительным данным, около 300 тысяч белорусов осуществляют трудовую деятельность за рубежом // БелаПАН [Электронный ресурс]. - 2000 - 2013. - Режим доступа: http://belapan.com/archive/2013/11/21/media_migration_v2/ Дата доступа: 22.11.2013

9. Сведения в отношении иностранных граждан, находящихся на территории Российской Федерации, в половозрастном разрезе (по состоянию на 2 февраля 2014 г.) // Федеральная миграционная служба [Электронный ресурс]. - 2014 - Режим доступа : http:/www.fms.gov.ru/about/statistics/data/details/54891/ Дата доступа : 28.02.2014

10. Чудиновских, О. Статистика трудовой миграции в странах сети МИРПАЛ / О.Чудиновских // Всемирный банк (The World Bank Group) [Электронный ресурс]. - 2013 - Режим доступа : http://siteresources.worldbank.org/INTECA/Resources/ChudinovskikhDec19Rus.doc Дата доступа : 12.09.2013

11. Чудиновских, О. Статистика трудовой миграции в странах сети МИРПАЛ / О.Чудиновских // Всемирный банк (The World Bank Group) [Электронный ресурс]. - 2013 - Режим доступа : http://siteresources.worldbank.org/INTECA/Resources/ChudinovskikhDec19Rus.doc Дата доступа : 12.09.2013

12. Артюхин М.И. Потенциал внешней миграции населения Беларуси: социологический анализ / М.И. Артюхин, С.А. Пушкевич // Доклады Национальной Академии Наук Беларуси. том 55. - №3 (май-июль) - 2011. - С. 115-118.

13. С начала года в Беларуси стало в 10 раз больше вакансий с зарплатой 4 млн рублей // ООО «ТУТ БАЙ МЕДИА» [Электронный ресурс]. - 2000-2012 - Режим доступа : http://finance.tut.by/news320365.html Дата доступа : 30.11.2012.

14. В самом бедном российском регионе зарплата выше, чем в белорусских областях // ООО «ТУТ БАЙ МЕДИА» [Электронный ресурс]. - 2000-2012 - Режим доступа : http://finance.tut.by/news322563.html Дата доступа : 30.11.2012. 
15. Солодовников, С.Ю. Необходима системная реформа белорусских предприятий / С.Ю.Солодовников // Бизнес-ревю. - 2012. - №9. - с. 66.

16. Беларусь не может себе позволить прежний объем госсубсидий из - за дисбалансов в макроэкономике - ВБ // ИА «Интерфакс-Запад» [Электронный ресурс]. - 1994-2012 - Режим доступа : http://www.interfax.by/news/belarus/101235 Дата доступа : 30.11.2012.

17. Белорусские мигранты зарабатывают больше миллиарда: в стране всеобщего равенства им платить не готовы // ООО «ТУТ БАЙ МЕДИА» [Электронный ресурс]. -2000-2013. - Режим доступа : http://news.tut.by/economics/373638.html Дата доступа : 22.11.2013

18. Лученок, А.И. Влияние миграционных потоков на социально-экономические показатели Беларуси / А.И. Лученок, И.В. Колесникова // Белорусская экономика: теория и практика [Электронный ресурс]. - 2013 - Режим доступа : http://uchenok.blogspot.com/2011/09/normal-0false-false-false-ru-x-none-x.html Дата доступа : 10.03.2013

19. Валетко, В. Влияние денежных переводов мигрантов на некоторые макроэкономические показатели Беларуси/ В. Валетко // Исследовательский Центр ИПМ [Электронный ресурс]. - 2013 - Режим доступа : http://www.research.by/webroot/delivery/files/KEF2013P2 03Valetka.pdf Дата доступа : 25.11.2013

20. Шиманович Г. Предложение рабочей силы в Беларуси: вызовы для экономической политики / Г. Шиманович, А. Чубрик // Исследовательский Центр ИПМ [Электронный ресурс]. 2013 - Режим доступа : http://www.research.by/webroot/delivery/files/pdp2013r01.pdf Дата доступа : 10.03.2013

21. Шахотько, Л. Незарегистрированная трудовая миграция из Республики Беларусь: состав мигрантов и их деятельность / Л. Шахотько // Трудовая миграция в СНГ: социальные и экономические эффекты : Сборник научных трудов / Отв. ред. Ж.А. Зайончковская - Москва, 2003. $-286 \mathrm{c}$.

22. Шиманович Г. Предложение рабочей силы в Беларуси: вызовы для экономической политики / Г. Шиманович, А. Чубрик // Исследовательский Центр ИПМ [Электронный ресурс]. 2013 - Режим доступа : http://www.research.by/webroot/delivery/files/pdp2013r01.pdf Дата доступа : 10.03.2013

23. Chubik, A. Costs and Benefits of Labour Mobility between the EU and the Eastern Partnership Partner Countries. Country Report: Belarus / A. Chubik, A. Kazlou // GDNet @ Global Development Network [Электронный pecypc]. - 2013 - Режим доступа : http://www.caseresearch.eu/sites/default/files/publications/CNSA_2013_462.pdf Дата доступа : 25.11.2013 